Egyptian J. Anim. Prod.,Vol. 31, Supplement Issue, Nov.(1994):215-230.

\title{
UTILIZATION OF BANANA, TOMATO AND POTATO BY-PRODUCTS BY SHEEP
}

\author{
A.M. Abd El-Gawad, W.H. Abd El-Malik2, Sabbah M. Allam ${ }^{1}$ \\ and I.M. El-Sayed ${ }^{2}$ \\ 1- Department of Animal Production, Faculty of \\ Agriculture, University of Cairo, Giza, Egypt, 2- Animal \\ Production Research Institute, Ministry of Agricutuler, \\ Egypt
}

SAMMARY

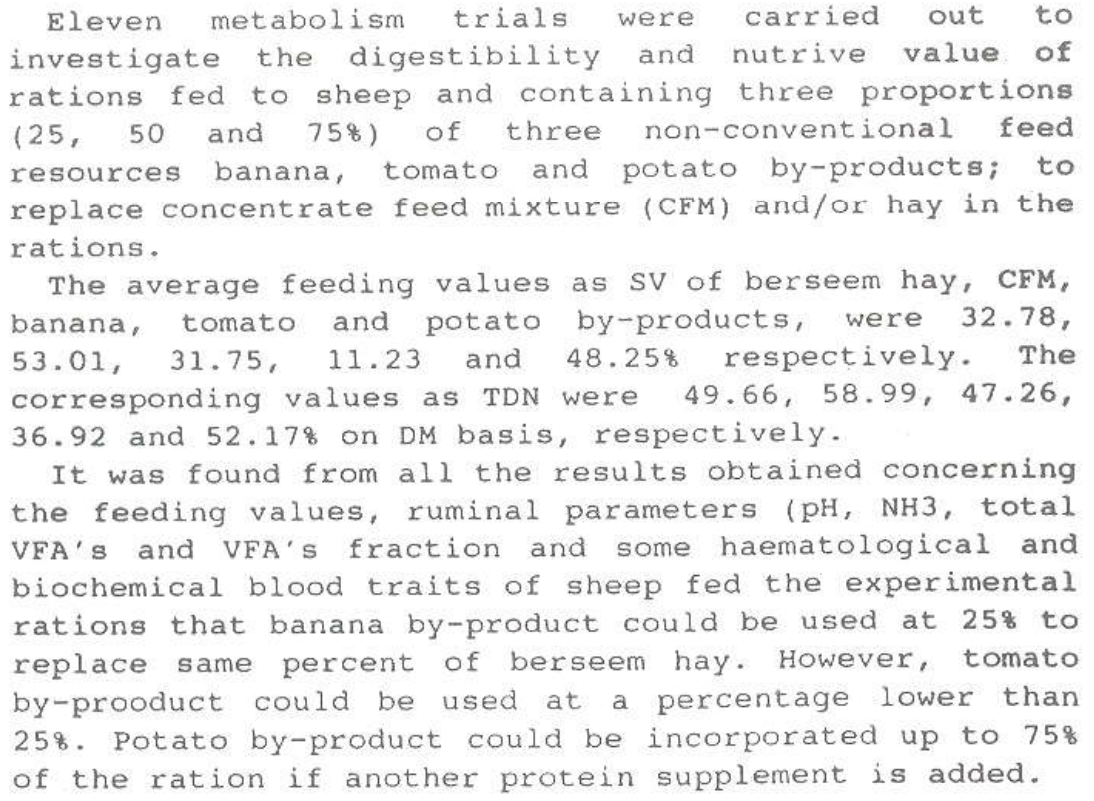

The average feeding values as SV of berseem hay, CFM, banana, tomato and potato by-products, were 32.78 , $53.01,31.75,11.23$ and $48.25 \%$ respectively. The corresponding values as TDN were $49.66,58.99,47.26$, 36.92 and 52.178 on DM basis, respectively.

It was found from all the results obtained concerning the feeding values, ruminal parameters ( $\mathrm{pH}, \mathrm{NH} 3$, total VFA's and VFA's fraction and some haematological and biochemical blood traits of sheep fed the experimental rations that banana by-product could be used at $25 \%$ to replace same percent of berseem hay. However, tomato by-prooduct could be used at a percentage lower than $25 \%$. Potato by-product could be incorporated up to $75 \%$ of the ration if another protein supplement is added.

Keywords: Utilization, banana by-product, tomato by-product, potato by-prodduct, sheep

Issued by Egyptian Society of Animal Production. 


\section{INTRODUCTION}

In Egypt, animals suffer from under feeding and mal-nutrition due to shortage of locally produced feeds which are not sufficient to cover the nutritional requirements of the existing livestock. The feeds shortage are also unevently divided between summer and winter. In winter season, berseem (Trifolium alexandrinum L.) the major forgage crop, covers 60 and 758 of yearly animal requirements from energy and protein respectively (Abou-Raya, 1967, El-Shazly, 1983, Abou-Akkada et al., 1984 and Dessoky and El-Nouby, 1990). However, in summer season, the available feeds (mainly concentrate and straws) cover only $39 \%$ and $22 \%$ of animal requirements for energy and protein, respectively (E1-Serafy, 1991).

Agro-industrial by-products (AIBP) refer to the by-products derived in the industry due to processing of the main products. They are less fibrous (potato byproducts) and have a higher nutrients content (tomato by-product) than straws, also some agricultural byproducts like banana by-product (leave and pseudostems) have nutrients nearest to hay. They can play an important role in meeting nutrient requirements of the animals as well as maintain a high intake of the roughage.

The objectives of the present study are to investigate the digestibility and the nutritive values, ruminal parameters and some blood haematoological and biochemical traits with sheep fed rations contained banana by-product (leaves and pseudostems), tomato and potato by-products.

\section{MATERIALS AND METHODS}

This study was undertaken during the year, 1991 at the animal house belonging to Animal Nutrition Department. Animal Production Researcch Institute, Ministry of Agriculutre and Land Reclamation. Eleven metabolism trials (21 days as a prelimanry and 7 days as a collection period for each) were undertaken to investigate the digestibilities and feeding values of the different experimental rations. In each trial three adult Barki x Merino cross breed rams of about one year old and $35 \mathrm{~kg}$ of body weight were used. They were housed 
individually in stainless steel metabolic cages.

Three non conventional feed resources (NCFR) were fed to sheep in different proportions with berseem hay and concentrate feed mixtures (CFM). Control ration was $50 \%$ hay + 508 CFM. Each NCFR was used at rate of 25,50 , or $75 \%$ from tested ration replacing 50 or 1008 from hay or 1008 hay and 508 from CFM. The used NCFR in this study were collected as they are produced, from factories and farms. Banana by-product are collected from banana farm near El-Kanater. Tomato by-product are collected from Kaha factory. They are mostly skins and little seeds. Potato by-product was collected from Chipsy Factory near Pyramids, Giza. It contains potato skins and the discarded potatoes. They were chopped and sun dried before fed to animals. The animals were fed at nearly maintenance level (Abou-Raya, 1967). A commercial mineral and vitamin mixture were added daily to the ration of each animal during the whole experimental periods to meet their requirements. Records for daily feed and water consumption, urine and faeces voided were kept for all trials.

Feeds, faeces and urine samples were analyzed according to the official Methods of Analysis Proceedures (A.O.A.C., 1980). Samples of used feedstuffs were analyzed for nutral detergent fiber (NDF), acid detergent fiber ( $A D F$ ) and acid detergent lignin (DAL), by the Van soest (1967) procedures. Cellulose and hemicellulose were determined by difference.

Rumen Liquor samples were taken from each animal during the last two days of the collection period of each experimental ration. They were taken before feeding, 2 hours, 4 hours and 8 hours post feeding using a rubber stomach tube. The rumen juice samples were strained through four folds of cheese cloth. As soon as the samples were taken, $\mathrm{pH}$ was measured and ammonia nitrogen was determined according to Conway method (1962). The total VFA's were determined as described by Abou-Akkada and El Shazly (1964) and individual VFA's were determined using a Perkin Elmer Model 3920 BGLC apparatus.

Blood samples were taken from each animal at the end of the collection period of each trial. Blood samples were taken from jugular vein and allowed to flow into acid washed heparinized tubes. Haematocrite value (PCV) and haemoglobin were determined using the whole blood 
(Maxine M. Benjamin, 1985). Blood plasma was used for determination of total protein, plasma urea, cholesterol glutamate oxalo-acetate transaminase (GOT) glutamtate pyruvate transaminase (GPT), and albumin (Pointe gcientific inc. Laboratory reagent and instrument) creatinine (bio-Merieux Laboratory reagent and insturuments) were analysed using the colorimetric methods. Globulin was determined by difference as follows:

Globulin = Total protein - Albumin

The data were analysed using general linear models using ANOVA procedures of SAS (1982). Means were separated using Duncan's Multiple range test when the main effect was significant.

\section{RESULTS AND DISCUSSION}

Chemical composition of the experimental feedstuffs and formulated rations

Chemical analysis of experimental feedstuffs on DM basis are presented in Table (1). Banana by-product showed similar chemical composition to that of berseem hay, but it contained low CP (11.66 vs $17.54 \%)$ and high ash $(20.26$ vs 14.468$)$.

Tomato by-product was similar in CP content to berseem hay, but it showed low NFE and ash and high CF content.

Potato by-product contained low CP, EE and CF and high NFE comparing to either berseem hay or concentrate fed miture (CFM).

Concerning fiber fractions contents, tomato, by-product had the highest values of acid dtergent fiber $(A D F)$, and lignin comparing to either hay, CFM or other experimental by-products. Banana by-product was similar with hay in ADF and lignin content. On the other hand, potato by-product had $A D F$ and lignine content similar to those of CFM content.

Banana by-product had higher contents of $\mathrm{CP}$ and ash than those reported by Gohl (1970) which might be due to the higher ratio of leaves to pseudostems of banana plants used in this sutdy. Chemical composition of tomato and potato by-products are in agreement with some deviations, with those reported by Abaza et al. (1987) for tomato by-product, Hulan et al. (1982) and Dickey et al. (1971) for potato by-product. 
Table (1): Chemical composition, digestibilities and fecding values of fecdstuffs used in formulating the experimental rations (DM basis).

\begin{tabular}{|c|c|c|c|c|c|}
\hline \multirow[b]{2}{*}{ Nutrient } & \multicolumn{5}{|c|}{ Experinicntaal feedstufs } \\
\hline & $\begin{array}{c}\text { Berseem } \\
\text { hay }\end{array}$ & CFM & $\begin{array}{c}\text { Banana by- } \\
\text { product }\end{array}$ & $\begin{array}{c}\text { Tomato } \\
\text { by-product }\end{array}$ & $\begin{array}{c}\text { Potato } \\
\text { by-product }\end{array}$ \\
\hline Dry matier & 89.74 & 90.00 & 92.22 & 93.96 & 88.85 \\
\hline Organic matter & 85.54 & 88.68 & 79.74 & 94.51 & 82.92 \\
\hline Crude protein & 17.54 & 17.75 & 11.66 & 16.11 & 12.25 \\
\hline Ether extract & 2.56 & 4.42 & 2.24 & 5.49 & 0.86 \\
\hline Crude fiber & 26.65 & 13.41 & 25.85 & 44.18 & 10.59 \\
\hline Nitrogen free extract & 38.79 & 53.40 & 39.99 & 28.73 & 59.27 \\
\hline Ash & 14.46 & 11.32 & 20.26 & 3.49 & 17.08 \\
\hline \multicolumn{6}{|l|}{ Eiber fractions: } \\
\hline Acid detergent fiber & 44.31 & 22.01 & 49.62 & $56.63^{\prime}$ & 23.92 \\
\hline Neutral detergent fiber & 85.53 & 42.98 & 73.56 & 68.74 & 66.54 \\
\hline Hemi-cellulose & 14.20 & 20.97 & 23.94 & 12.11 & 44.28 \\
\hline Cellulose & 28.38 & 15.72 & 32.94 & 27.42 & 7.58 \\
\hline Lignin & 8.98 & 3.98 & 9.22 & 23.90 & 4.80 \\
\hline Digestion coefficients \%: & $*$ & $*$ & *** & $* * *$ & $* * *$ \\
\hline Dry matter & $54.92^{\mathrm{a}}$ & $6702^{\mathrm{a}}$ & $45.46^{\mathrm{b}}$ & $27.34^{\mathrm{c}}$ & $41.92^{b}$ \\
\hline Organic matter & $56.34^{b}$ & $67.64^{a}$ & $54.95^{b}$ & $35.67^{\mathrm{C}}$ & $64.12^{\mathrm{a}}$ \\
\hline Crude protien & $62.21^{\mathrm{a}}$ & $69.61^{\mathrm{a}}$ & $67.066^{\mathrm{a}}$ & $47.10^{b}$ & $41.37^{\mathrm{C}}$ \\
\hline Ether Extratci & $40.55 \mathrm{ab}$ & $80.62^{\text {ab }}$ & $4.4 .49^{b}$ & $54.53 \mathrm{a}$ & $\therefore 26.03^{c}$ \\
\hline Crude fiber & $37,48^{b}$ & $40.99^{a}$ & $4938^{3}$ & $32.96^{\mathrm{b}}$ & $25.58^{\mathrm{C}}$ \\
\hline Nitrogen free extract & $66.78^{a b}$ & $72.04^{\mathrm{b}}$ & $62.54^{b}$ & $34.68^{\mathrm{c}}$ & $73.99^{\mathrm{a}}$ \\
\hline \multicolumn{6}{|l|}{ Eeeding value \% } \\
\hline TDN & $49.66^{a}$ & $58.99^{\mathrm{b}}$ & $47.26^{\mathrm{a}}$ & $36.92^{\mathrm{b}}$ & $52.17^{\mathrm{a}}$ \\
\hline SV & $32.78^{b}$ & $53.01^{\mathrm{b}}$ & $31.75^{b}$ & $11.23^{\mathrm{c}}$ & $48.25^{\mathrm{a}}$ \\
\hline DCP & $10.91^{n}$ & $12.34^{b}$ & $7: 56^{6}$ & $749^{\mathrm{b}}$ & $5.07 \mathrm{c}$ \\
\hline
\end{tabular}

- Obtained directly

- Obtained indirectly using $50 \%$ of the feedstuff or the by-products and $50 \%$ berscem, hay.

* Obtained indirectly using $50 \%$ of the feedstuff or the by-produced $50 \%$ CFM.

Banana, Tomato and potato by-prduct were compared with berseem hay

$a, b, c$ means in the same line with different superscript differ significantly $(P<0.05)$. 
Digestion coefficients and feeding value of experimental feedstuffs

The results are summarized in Table (1), comparing the results of digestioon coefficients of banana, tomato and potato by-products as roughage feedstuffs (AIBP) with that of the hay, it could be seen that banana had significantly higher $\mathrm{CP}$ and $\mathrm{CF}$ digestibilities than tomato and potato by-products. On the other hand, potato by-product showed the highest values of $O M$ and NFE digestibilities. Regarding the feeding value as TDN and sv, banana by-product showed a close value to that hay, while potato by-products was highest and tomato by-product was the lowest. Banana and tomato by-products had nearly the same value of DCP. However, they were significantly higher than potato by-product but significantly lower than hay.

Tomato by-product used the present study had less CP and higher CF content than those reported by other workers (Abou-Akkada et al., 1975 and Abaza et al., 1987). This might be responsible for decreasing the digestion coeffients and its feeding value. The digestion coefficients for the different nutrients of banana by-product were lower, except CP, than those reported by Gohl (1970) for the whole banana plant and that reported by Blaha and Mudrik (1981) for leaves, leaf stems and part of banana pseudostem. The differences in the ratio of banana plant components may be responsible for these differences. The TDN of potato by-product was similar to that reported by Dickey et al, (1971).

Digestioon coefficients and feeding value of the experimental rations

The results are summarized in Table (2) using $25 \%$ of banana by-product in the ration to replace berseem hay did not affect practically the feeding value of the ration compared to the control ration $(50 \%$ berseem hay and $50 \%$ or $75 \%$ CFM). However, the DCP was significantly reduced from $12.33 \%$ for control ration to only 9.698 . Increasing the percentage of banana by-product in ration to $50 \%$ significantly decreased the digestion coefficients and feeding value of the rations than that of control ration. 
Egyprian J. Anim. Prod. (1994).

Iable (2) Chemical composition, digestibilaties atd fecding value of formaulated rations

\begin{tabular}{|c|c|c|c|c|c|c|c|c|}
\hline \multirow[b]{2}{*}{ Ration } & \multirow{2}{*}{$\frac{\text { Level of }}{\text { by-Problis }}$} & \multicolumn{7}{|c|}{ DM Conposition } \\
\hline & & DMA & (3) & EE & $\mathrm{CP}$ & $\mathrm{CF}$ & NFE & Anth \\
\hline \multicolumn{9}{|l|}{ (1000:shay) } \\
\hline $50 \% 6$ hay. & & 8974 & 853.4 & 17.34 & 2.86 & 26.65 & 38.79 & 14.46 \\
\hline \multicolumn{9}{|l|}{$903 \mathrm{CFM}$} \\
\hline Panana & . & $89 \times 4$ & 8754 & $1 \times 18$ & 3.04 & 20.82 & 45. 50 & 1246 \\
\hline by. & 25 & 9199 & 8121 & 1409 & 2.80 & 19.39 & 46.73 & 16.79 \\
\hline Protuct & 50 & 91.07 & ห) 40 & 1426 & 2.88 & 23.09 & 41.07 & 18.60 \\
\hline Twatiath & 74 & 2211 & 8065 & 1294 & 2.17 & 27.16 & 38. 38 & 19.35 \\
\hline by. & 2 & 9087 & 91.18 & 17.27 & 471 & 22.01 & 47.19 & $\pi 22$ \\
\hline Boflus & so & 91.57 & 93.18 & 16.75 & 9.37 & 27.23 & 43.93 & 6.82 \\
\hline Potate & 79 & 9269 & 9341 & 16.99 & 4.41 & 3967 & 36.38 & 6.39 \\
\hline nis. & 23 & 88.37 & 8772 & 15.37 & 2.59 & 10.08 & 53.68 & 12.28 \\
\hline \multirow[t]{2}{*}{ nimatica } & 50 & 8989 & 96,34 & 1490 & 2.54 & 1102 & 57.88 & 13.66 \\
\hline & 73 & 8266 & 8589 & 1298 & 192 & 11.19 & 59.84 & 14.11 \\
\hline
\end{tabular}

\begin{tabular}{|c|c|c|c|c|c|c|c|c|c|c|}
\hline & hay CIM & DM & $6 \mathrm{Mt}$ & $C T$ & FE & $C 8$ & -0 & & & \\
\hline $\mathrm{Hay}+\mathrm{CF} m$ & & & & & & & & & & \\
\hline & 50.90 & 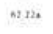 & $n n$ & $\therefore s$ & at une & $a n k$ & tarenest & $1230 \%$ & 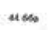 & s. alowosed \\
\hline Cinered & 2* & w not & $\because z$ & a 1 & wand & $\sin \operatorname{san} x$ & newar & reseser. & +4 & 5360od \\
\hline Aomens: & " & $\cdots+\infty$ & $\sim \infty$ & nos & senst & sz nath & "Shat & - is oute & 37.36 & sinos \\
\hline in Proderst & $\%$ & 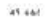 & sonte & "ass & $\|$ (1) & path & $912 \mathrm{at}$ & $\cos \theta$ & $2532 \times$ & $41 \pi$ \\
\hline & 24 & $\cdots n$ & $x(0028$ & 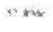 & of roned & $n \times n$ & os remen & 8176 & $33 \times$, & wossent \\
\hline Tansato & 40 & atid & nint & wotit & 67 mater & \$02018 & rosa & .00 & seer & cost \\
\hline Ay Proxber & 75 & and & $\cdots+4$ & rour & "sos & nn & $a \times \infty$ & 92 rath & sem & ssth \\
\hline & 25 & werer & $4+60$ & rase & nowen & 3. & mowares & $=m$ & aroued & sorbed \\
\hline Rexato & 50 & $" n$ & ns & $* 18$ & s llow & b. 616 & nomes & $04 x$ & rast & $6190 \times$ \\
\hline by provent & 75 & 4326 & $\infty \infty$ & soor. & Nom & 2492 & क & sobst & 3 tene & nosond \\
\hline
\end{tabular}


Replacing half of the berseem hay (25\%) of the ration by tomato by-product in sheep ration decreased significantly the digestion coefficients and the feeding value of the ration than those of the control ration (50:50 hay: CFM). Increasing the percentage of tomato by-product in the ration to 50 or 75 on the expense of berseem hay and CFM increased significantly the reduction in the feeding values of the fed rations. These adverse effect may be due to the high CF content and lignine content in tomato by-product. This by-product contained high percentage from tomato skins and less percentage from tomato seeds, this composition reflected on increasing CF especially lignine contents.

Incorporating up to 75 of potato by-product in the ration at the expense of hay and part of the CFM (25\%) had a beneficial effect on the feeding value as SV and TDN. However, the feeding values as DCP were gignificantly reduced than those of control ration which was due mainly to the reduction of $C P$ digestibility compared to the control ration. Increasing potato by-product level in the ration decreased CF digestibility. This may be due to its higher content of soluble carbohydrate (NFE) compared to hay or CFM. Feeding high levels of carbohydrates stimulated growth of starch-digesting microbes at the expense of cellulotoc microorganisms (El-Shazly et al. 1961).

Positive nitrogen balance were found for all experimental rations fed to sheep. This indicated that the nitrogen content of all rations was enough to meet the nitrogen requirement of adult sheep.

Effect of feeding experimental rations on some ruminal parameters

A significant effects of sampling time and the type of ration on ruminal $\mathrm{pH}$, ammonia $-\mathrm{N}$ and total volatile fatty acids (TVFA) were found for all the fed rations (Table 3). Ruminal pH values were decreased and those of ammonia $-\mathrm{N}$ and TVFA were increased as the sampling time advanced post-feeding. Most of the decrease and increase occurred during the first $2-4$ hours after feeding then stsarted to change towards the figures recorded before feeding. 


\begin{tabular}{|c|c|c|c|c|c|c|c|c|c|c|c|c|c|c|}
\hline 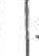 & & $\stackrel{\vec{m}}{\vec{F}}$ & $\stackrel{7}{m}$ & $\stackrel{\circ}{-1}$ & & नै & ¿̊ & 5 & $\circ$ & : & 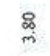 & & & $:$ \\
\hline & & 曾 & $\frac{8}{6}$ & $\frac{8}{\frac{8}{2}}$ & $\frac{8}{8}$ & $=$ & $\frac{\gamma}{8}$ & 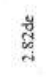 & $\pi$ & s & $\underset{\sim}{\infty}$ & E & & a \\
\hline 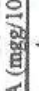 & & $\begin{array}{l}\text { ह } \\
\text { न } \\
7\end{array}$ & $\frac{8}{6}$ & $\begin{array}{l}\frac{8}{5} \\
\text { 总 }\end{array}$ & ? & $\vec{a}$ & $\frac{y}{b}$ & $\frac{y}{a}$ & $\stackrel{n}{2}$ & 5 & $\begin{array}{l}\frac{8}{8} \\
\frac{8}{2} \\
\frac{2}{6}\end{array}$ & \begin{tabular}{l}
8 \\
$\stackrel{8}{8}$ \\
\hdashline
\end{tabular} & 㞼 & 8 \\
\hline & & \begin{tabular}{l}
8 \\
8 \\
8 \\
\hdashline
\end{tabular} & 胥 & 疍 & & $\Rightarrow$ & $\overbrace{n}^{2}$ & $\begin{array}{l}\text { g } \\
\text { g. }\end{array}$ & 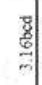 & a & कै & $\stackrel{\mathrm{s}}{\mathrm{s}}$ & $\frac{\mathrm{g}}{\mathrm{s}}$ & 7 \\
\hline 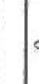 & & s. & 晃 & 㫫 & & : & 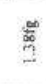 & $\underline{\underline{5}}$ & & s & $\frac{8}{8}$ & 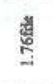 & $\frac{\pi}{3}$ & $\approx$ \\
\hline 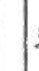 & 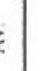 & बू. & $\stackrel{8}{\stackrel{8}{\infty}}$ & $\stackrel{7}{0}$ & & $\frac{6}{6}$ & $\tilde{n}$ & క్ & : & : & $\frac{\hat{\eta}}{\vec{A}}$ & ई̊ & $\stackrel{a}{\square}$ & $\stackrel{\circ}{9}$ \\
\hline . & & ร్ & 节 & $\begin{array}{l}\text { 䑁 } \\
\text { ב }\end{array}$ & & $\exists$ & 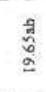 & $\begin{array}{l}\stackrel{8}{8} \\
\stackrel{8}{8}\end{array}$ & : & : & $\underset{\substack{g \\
\infty}}{\underline{n}}$ & $\begin{array}{l}\frac{8}{8} \\
\frac{8}{8} \\
\underline{-2}\end{array}$ & ఫ్ & ? \\
\hline & & $\frac{2}{4}$ & $\stackrel{\nexists}{g}$ & 胥 & & 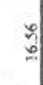 & $\frac{8}{\frac{8}{n}}$ & $\frac{8}{9}$ & 部 & : & $\stackrel{g}{g}$ & $\begin{array}{l}8 \\
d \\
d\end{array}$ & : & ร์ \\
\hline & & 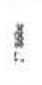 & 竞 & $\underset{N}{ }$ & & . & $\frac{7}{n}$ & 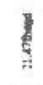 & 缕 & ว & $\frac{8}{8}$ & $\frac{e}{a}$ & : & a \\
\hline & o & $\stackrel{g}{8}$ & 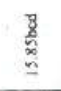 & 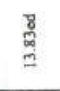 & & 용 & $\frac{8}{6}$ & $\begin{array}{l}8 \\
8 \\
\end{array}$ & 音 & $\stackrel{\leftrightarrow}{*}$ & हैं & 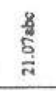 & 㺃 & \\
\hline & $\varepsilon$ & ई & : & z & & $:$ & $\stackrel{q}{n}$ & 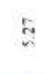 & 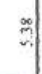 & 0 & $\stackrel{2}{\sim}$ & $\stackrel{8}{8}$ & 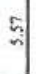 & \\
\hline & 。 & 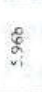 & $\stackrel{7}{7}$ & $\frac{7}{7}$ & & ? & 丞 & $\frac{g}{n}$ & : & of & $\frac{8}{2}$ & 宽 & ఫ & 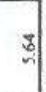 \\
\hline & & 敢 & $\frac{\hat{g}}{8}$ & $\frac{9}{2}$ & & $\Rightarrow$ & है & $\stackrel{Z}{3}$ & 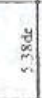 & 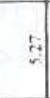 & $\begin{array}{l}\frac{8}{2} \\
\frac{2}{2}\end{array}$ & $\frac{8}{8}$ & శ్ & \\
\hline & 4 & $\frac{8}{6}$ & $\underset{:}{\mathscr{B}}$ & $\vec{E}_{0}^{n}$ & & 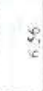 & 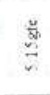 & 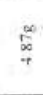 & : & 3 & $\frac{8}{5}$ & 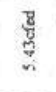 & ్ㅐㅇ & \\
\hline & b & f & $\stackrel{\not 2}{\not}$ & $\stackrel{B}{S}$ & 4 & 4 & 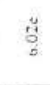 & 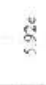 & $\mathrm{g}$ & $\Leftrightarrow$ & $\frac{8}{7}$ & 學 & 응 & \\
\hline & 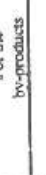 & $\overrightarrow{\mathrm{g}}$ & a & 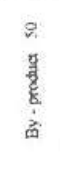 & & & $\begin{array}{l}n \\
n \\
\text { g. }\end{array}$ & 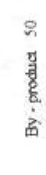 & & & 产 & 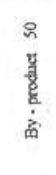 & & \\
\hline
\end{tabular}


The vlues of $\mathrm{pH}$ in the present study are in harmony with those of Rakha (1988) who summarized the work of several workers and reported that the normal value of ruminal $\mathrm{pH}$ of sheep ranged between 4.96 and 7.92 . In this connection Koufmann (1972) stated that the regulation mechanism of the ruminant are not directed towards maintaining a medium or normal $\mathrm{pH}$, but rather for adjusting the $\mathrm{pH}$ according to the composition of the ration of that value most appropriate for the degradation of specific type feed. The average of ruminal $\mathrm{NH} 2 \mathrm{-N}$ for all the experimental fed rations ranged between 16.12 and 21.61 compared to $26.93 \mathrm{mg} / 100$ $\mathrm{ml}$ for control ration. These value insure reasonbale supply of $\mathrm{N}$ for rumen microorganism and host animal. These results are in harmony with those of satter and Roffler (1977) and Mehrz et al. (1977). Tomato by-product rations showed the least overall average for TVFA compared to control or other, experimental rations.

Conserning the molar proportions $\%$ of the individual VFA (Acetic, propionic and butyric acids and acetic/propionic ratio), a significant affect of sampling time and type of ration were found (Table 4). The values are within the range reported by Rakha (1988). In this connection El-Shazly (1952) and Reid et al. (1957) pointed out that the nature of the feed had considerable influence both on the total concentration of VFA in the rumen and on the proportion of the individual acids.

As the levels of VFA and ammonia-N (as product of fermentation and breakdown of dietary proteins) have been used as parameters of ruminal activity by Abou-Akkada and Osman (1967), it could be concluded that the tomato by-product rations had the lowest ruminal activity compared to other experiment and control rations which might be responsible for their lower digestibility and feeding value.

Effect of feeding the experimental rations on some blood parametrs of sheep

The results are summarized in Table (5). No significant differences between rations containing the non-conventional feed resources used compared to control ration concerning some haematological parameters ( $\mathrm{Hb}$ and PCV) and biochemical constitutents (albumin, glubulin, total protein, urea $-N$, cholesterol and creatinine) and 
Egyprian J. Anim. Prod. (1994).

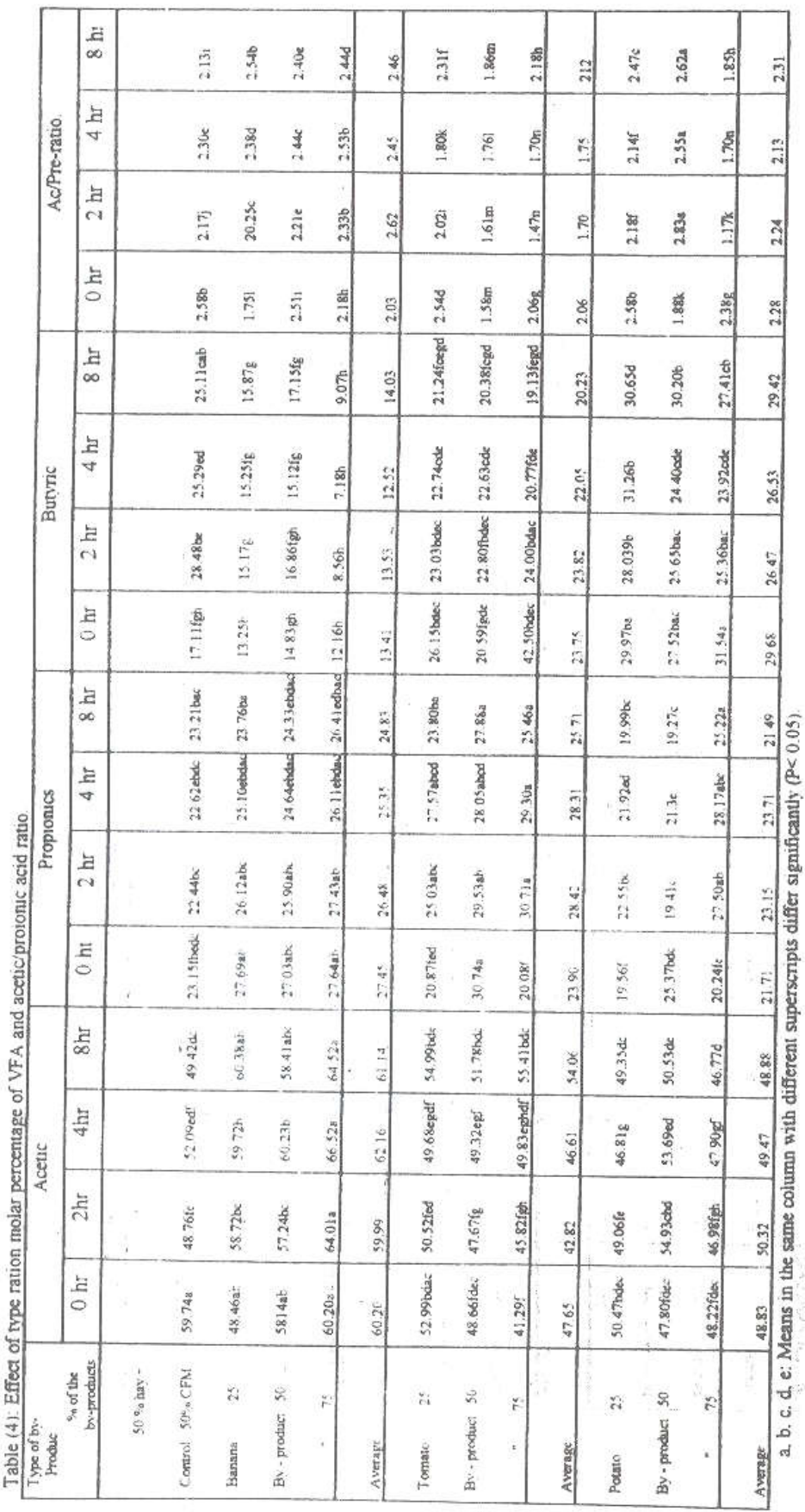




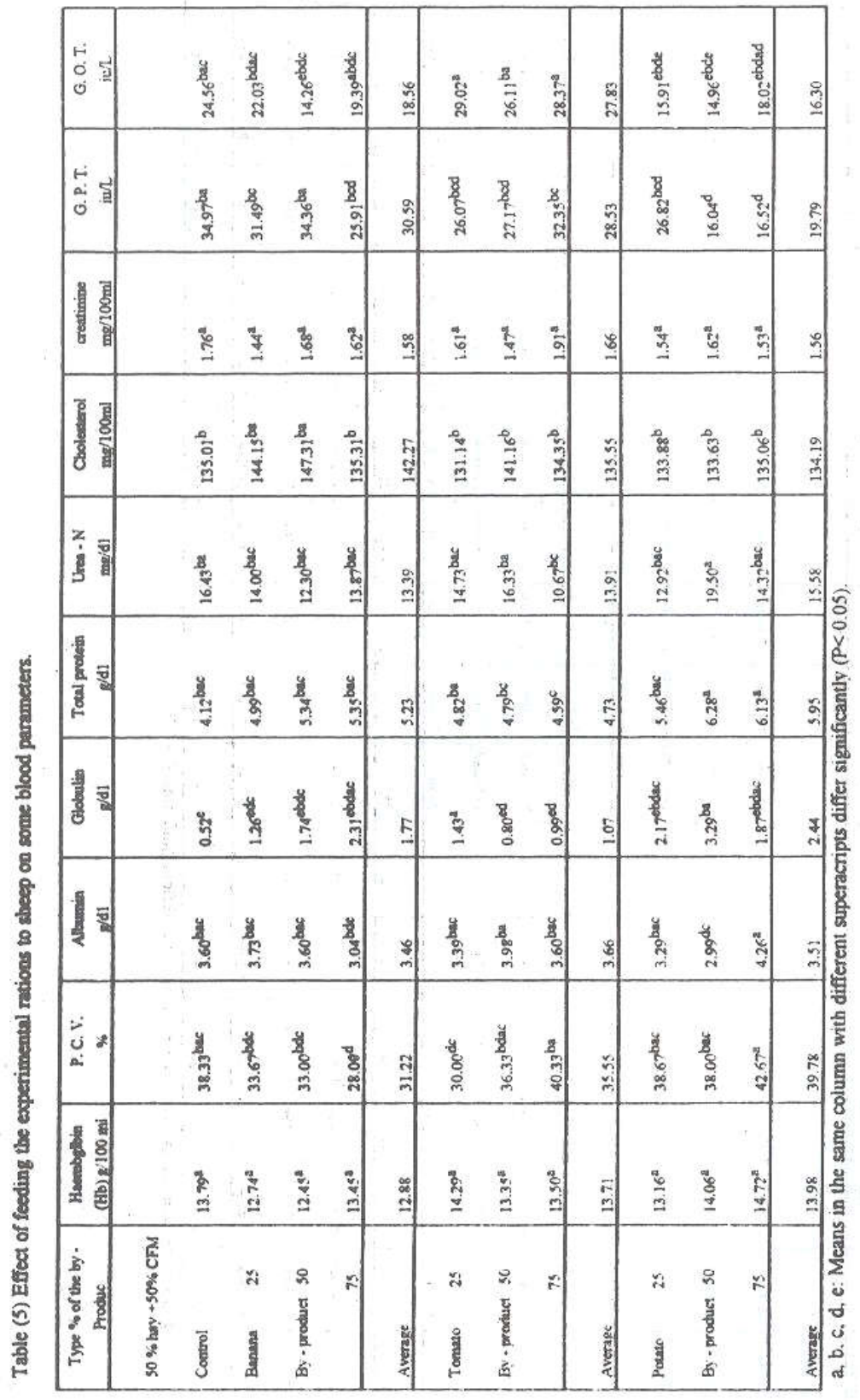


serum enzymes (GOT and GPT) of blood serum of sheep, which insures no harmful effect on nutrition status and kidney or liver functions. The values obtained in the present study were within the range reported by Rakha (1988) taken from several studies on normal sheep blood.

From all the results obtained concerning the digestibility coefficients and feeding values, ruminal parameters and haematological and biochemical parameters of blood and blood serum, the following could be concluded:

a) Banana by-product could be used at $25 \%$ in the ration to replace the same percentage of berseem hay. b) Tomato by-product could be used at a percentage lower than 25\%. C) Potato by-product could be used up to $75 \%$ of the ration, if a high protein supplement is added.

\section{REFERENCES}

Abaza, M.A., B.E. Nour, B.E. Birganu and K. El-Shazly, 1987. Nutritive value of vegetable and fruit wastes as animal feeds. Alex. J. Agric. Res. (Egypt), 32 (2): 75-83.

Abou-Akkada, A.R. and K. El-Shazly, 1964. Effect of absence of ciliate protozoa from the rumen on microbial activity and growth of lambs. Applied microbiology, 12: 384-389.

Abou-Akkada, A.R., M.M. Farid, Wardah, M.N. Hassan, Al-Shorbagy, M. Bayoumi and A. Alwash, 1984. Evaluation of present status and potential development of animal feed resources in Arab countries, the national study. Arab orgnization for Agric. Development (AOAD), Khartoum and the Arab Centre for the Studies of Arid Zones and Dry Lands (ACSAD), Damascus, ACSAD/AS/P53/1984 (in Arabic)

Abou-Akkada, A.R., A. Khalil, M.A. Kosba and M.M. Khalifah, 1975. Effect of feeding residues of tomato canning on the performance of laying hens. Alex. J. gric. Res. 23 (1): 9-14.

Abou-Akkada, A.R. and H.E. Osman, 1967. The use of ruminal ammonia and blood urea as an index of the nutritive value of proteins in some foodstuffs. J. Agric. Sci. 69:25-31.

Abou-Raya, A.K., 1967. Animal and poultry nutrition 1st ed. Pub. Dar El-Maaref Libr. (in Arabic). 
A.O.A.C., 1980. Officil Methods of Analysis of the Associaation of official Analytical Chemists. 13th. Ed. Washington, USA.

Blaha, J. and Z. Mudrik, 1981. A study on the nutritive value of banana leaves and pseudostems (NAR, 56 (10: 3988, 1986).

Conway, E.J., 1962. "Microdiffusion Analysis and Volumetric Error". 5th Ed., Crosky Lockwood and Sona Ltd., London.

Dessouky, A. and H. El-Nouby, 1990. Increasing animal feed resources for rasing animal weath. Anim. Prod. Res. Instit. and GTZ Project Bull. (In Arabic).

Dickey, H.C., H.A. Leonard, S.D. Musgrave, and H.S. Young, 1971. Nutritive characteristcs of dried potato by-product meal for ruminants, J. Dairy Sci., $54(6)$ : 876-879.

El-Serafy, A.M., 1991. Efficiency of converting Egyptian clover to milk and meat production in two models of animal production in A.R.E. during years, 1985 and 1990. 3rd Sci. Symp. on Animal, Poultry and Fish Nutrition, Sakha, Kafx El-Sheikh, 26-28 Nov. pp. 119-133. (In Arabic).

El-Shazly, K., 1952. Degradation of protein in the rumen of sheep. 2. The action of rumen microorganisms on amino acids. Biochem., J. 51:647-652.

El-Shazly, K., B.A. Deherily, and R.R. Johnson, 1961. Effects of starch on the digestion of cellulose in vitro and in vivo by rumen microorganims. J.Anim. Sci. 20, 268-274.

El-Shazly, K., 1983. Utilization of low quality roughages with special reference to developing countries. Proceeding of a Workshop on Applied Research. Held in Alexandria, Egypt. 1-11 March.

Gohl, B.O., 1970. "Tropical Feeds" FAO Anim. Prod. and Health series, No. 12, FAO, Rome, Italy.

Hulan, H.W.; F.G. Produdfoot, and C.G. Zaradakasm, 1982. Potato waste meal. 1. Compositional analyses. Can. J. Anim. Sci. 62:1161.

Koufmann, W., 1972. Uber die regnierung des plPH wertesim hauben-panasanrm der wiederkauer. Tievartl. Umschau 27, 324-328 (CAB Abstract Publication Data).

Maxine, M. Benjamin, 1985. "Outline of veterinaary clinical pathology" First Published in India, New 
Delhi - 110020 .

Mehrez, A.Z., E.R. Orskov, and T. McDonald, 1977. Rates of rumen fermentation in relation to ammonia concentration Brit. J. Nutrition, 38: 477-485.

Rakha, G.M., 1988. Studies on the effect of usingagro-industrial by-products on health and production of some farm animals, Ph.D. Thesis, Fac. of Vet. Med., Cairo Univ.

Reid, R.L., J.P.Hogan and P.K. Briggs, 1957. The effect of diet on individual volatile fatty acids in the rumen of sheep, with particular reference to the effect of low rumen $\mathrm{pH}$ and adaptation on high starch deits. Austral J.Agric., Res. 8:691-710.

SAS, 1982. User's guide statistics, SAS Inst. Cary. NC. Releigh.

Satter, L.D. and Roffler, 1977. Relationship between ruminal ammonia and protein nitrogen utilization by ruminants. In Tracer studies on non-protein nitrogen for ruminants, 3. Vienna, Austria International Atomic Agency, 119-138.

Van Soest, P.J., 1967. Development of a comprehensive system of feed analysis and its application to forages, J. Anim. Sci. 26:119-124. 


$$
\begin{aligned}
& \text { إستفادة الأغنام من مخلفات الموز، الطماطم والبطاطس } \\
& \text { عبد الرحمن عبد الجبو اد ا - وهبه حنـا عبد الملكب - صباح محمـود } \\
& \text { علام ا- إبراهيم السبيد الجيخ }
\end{aligned}
$$

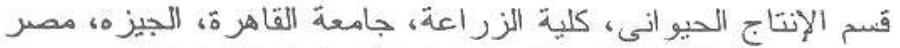

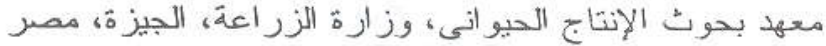

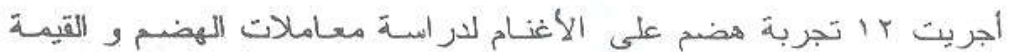

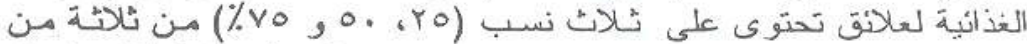

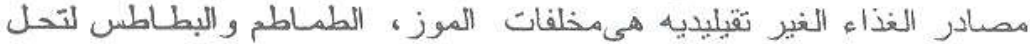

$$
\begin{aligned}
& \text { محل المخلوط المركز و الدريس أو أبراء أبهما. }
\end{aligned}
$$

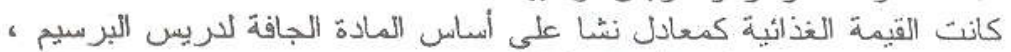

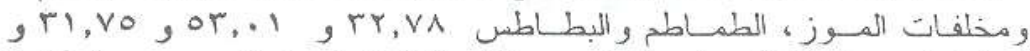

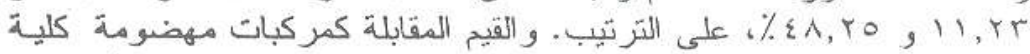

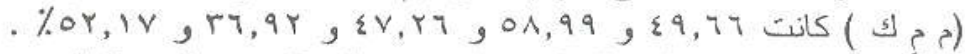

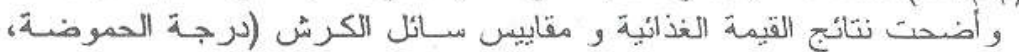

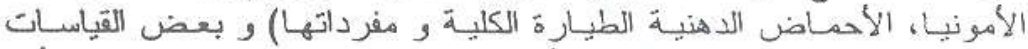

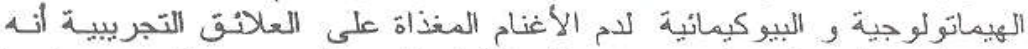

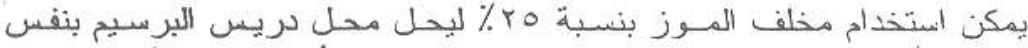

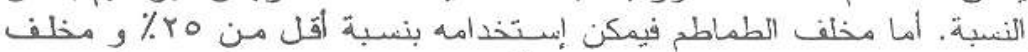

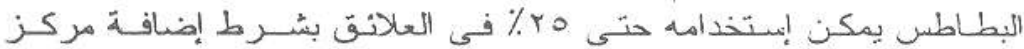

$$
\begin{aligned}
& \text { بروتيني منانب. }
\end{aligned}
$$

